\title{
Population genetic structure of the perlemoen Haliotis midae in South Africa: evidence of range expansion and founder events
}

\author{
B. S. Evans ${ }^{1,2,4, *}$, N. A. Sweijd ${ }^{3}$, R. C. K. Bowie ${ }^{3,5}$, P. A. Cook $^{3}$, N. G. Elliott ${ }^{2}$ \\ ${ }^{1}$ School of Zoology, University of Tasmania, GPO Box 252-05, Hobart, Tasmania 7001, Australia \\ ${ }^{2}$ CSIRO Marine Research, GPO Box 1538, Hobart, Tasmania 7001, Australia \\ ${ }^{3}$ Department of Zoology, University of Cape Town, Private Bag, Rondebosch 7701, Cape Town, South Africa \\ ${ }^{4}$ Present address: School of Marine Biology and Aquaculture, James Cook University, Townsville, \\ Queensland 4811, Australia \\ ${ }^{5}$ Present address: Department of Zoology, University of Stellenbosch, Private Bag XI, Matieland 7602, South Africa
}

\begin{abstract}
Genetic diversity in Haliotis midae, a highly valued and heavily exploited marine gastropod, was assessed using 3 marker types across samples from the species' range in South Africa. Variation was compared at 7 allozyme loci, 2 regions of mitochondrial DNA and 3 microsatellite loci. We conclude that populations of $H$. midae on either side of Cape Agulhas represent 2 independent reproductive stocks. The area of transition between the stocks coincides with oceanographic features of the region. Evidence from all 3 types of genetic marker indicates an isolated introduction event to the east of Cape Agulhas, and subsequent range expansion in an easterly direction. The disparity between allozyme data and the other 2 forms is seen as further evidence for the presence of balancing selection at allozyme loci.
\end{abstract}

KEY WORDS: Allozymes · Mitochondrial DNA $\cdot$ Microsatellites $\cdot$ Abalone Resale or republication not permitted without written consent of the publisher

\section{INTRODUCTION}

The diversity and richness of the marine flora and fauna of the southern African coast are divided into recognised biogeographic zones that are strongly influenced by complex oceanography and coastal habitats (Turpie et al. 2000, Beckley et al. 2002). The cool, temperate SW coast is influenced by southerly winds and cool water upwelling, while the warm temperate SE coast is influenced by the southward flowing warm Agulhas Current. The 2 systems meet at a transition region between Cape Point and Cape Agulhas (Fig. 1).

There are 5 recognised species of abalone on the South African coast (Geiger 2000). Three (Haliotis midae, H. parva, H. spadicea) have distributions to the east and west of Cape Agulhas, and of these H. midae, the perlemoen, is the only commercial species. The other 2 species ( $H$. queketti, H. speciosa) have distribu- tions restricted to the eastern Cape coastline. Fossil records of an extinct species, $H$. saldanhae occur in the western Cape, both within the current range of $H$. midae and along the NW Cape, south of the Orange River. $H$. saldanhae is represented by 2 million year old (myo) fossils in sediments up to $500 \mathrm{~km}$ north of the current distribution of any abalone species on the South African coast (Kensley 1972, Kensley \& Pether 1986).

In a growing number of population genetic studies of marine organisms, contrasting results have been obtained with different genetic markers (reviewed by Avise 1994, Ward \& Grewe 1994, Hilbish 1996, Shaklee \& Bentzen 1998). In our investigation of the Haliotis midae population genetic structure, we compare the 3 most commonly used methods for assessment of genetic diversity in marine species: allozyme electrophoresis, mitochondrial DNA restriction fragment length polymorphism, and microsatellite DNA variation. 
In this study, variation at these 3 marker types was examined in samples of $H$. midae taken from localities throughout the species' range. The degree of genetic variability measured at each marker was assessed, and the hypothesis that no genetic substructure exists throughout its range was tested.

\section{MATERIALS AND METHODS}

Samples. Samples of Haliotis midae were obtained from 18 localities within, and representative of, the distribution of the species (Fig. 1). Five collections for allozyme analyses (west to east distribution: $\mathrm{Pa}, \mathrm{Hg}$, Ms, Cr and Wa) were made by divers in 1994, with biopsies of gill tissue, adductor muscle and hepatopancreas obtained from each individual, instantly frozen and stored in liquid nitrogen. Samples for mitochondrial DNA analysis were obtained in 1996 from 16 localities (Da, Me, Ri, Sp, Cp, Hg, Bb, Gb, Qp , Su, Ms, $\mathrm{Nv}, \mathrm{St}, \mathrm{Cr}, \mathrm{Bi}$ and $\mathrm{Wa}$ ). These samples were transported live to the laboratory, where gill tissue and adductor muscle were dissected out. The samples for microsatellite analysis included 5 of the 1996 samples (Da, Ri, Ms, St and $\mathrm{Cr}$ ) and a new sample (Kl) consisting of gill tissue dissected from a commercial catch taken in 2000. All samples were held in the laboratory at $-70^{\circ} \mathrm{C}$ until required for analysis.

Genetic analysis. Total DNA was extracted for mitochondrial DNA and microsatellite analyses using the cetyltrimethylammonium bromide (CTAB) method described by Grewe et al. (1993).
Allozymes: Starch (12.6\% Sigma) gel electrophoresis was employed using the methods and histochemical staining protocols described in Schaal \& Anderson (1974) and Benson \& Smith (1989). The 4 buffer systems used were: AC (continuous, 0.04 M citric acid, pH 6.1), RW (discontinuous, electrode-0.06 M LiOH, $0.3 \mathrm{M}$ boric acid, $\mathrm{pH} 8.0$; gel-0.03 M Tris, $0.005 \mathrm{M}$ citric acid, pH 8.7), TEB (continuous, $0.087 \mathrm{M}$ Tris, 0.0087 $\mathrm{M}$ boric acid, $0.001 \mathrm{M}$ EDTA, pH 9.0) and TEM (continuous, $0.1 \mathrm{M}$ Tris, $0.001 \mathrm{M}$ EDTA, $0.001 \mathrm{M} \mathrm{MgCl}_{2}$, $\mathrm{pH}$ 7.8). Gels were run at $30 \mathrm{~mA}$ at $4^{\circ} \mathrm{C}$ for 4 to $5 \mathrm{~h}$ (except with TEM buffer gels run overnight). Following an initial survey of 31 enzyme systems, 7 loci that could be consistently resolved were used in the study of genetic variability. The 7 loci were: argenine kinase (ark-1, E.C. 2.7.3.3, all tissues, buffer RW), diaphorase (dia-1, E.C. 1.6.2.2, hepatopancreas, buffer RW), glucose-6-phosphate isomerase (gpi-1, E.C. 5.3.1.9, all tissues, buffer AC), malate dehydrogenase (mdh-1, E.C. 1.1.1.37, all tissues, buffer AC), malate enzyme (me-1, E.C. 1.1.1.40, all tissues, buffer AC), mannose-6- phosphate isomerase (mpi-1, E.C. 5.3.1.8, gill and adductor muscle, buffer TEB) and phosphoglucomutase (pgm-1, E.C. 5.4.2.2, all tissues, buffer RW). Alleles were numbered according to the mobility of their product relative to that of the most common allele observed in the Paternoster samples, which was designated '100'.

Mitochondrial DNA: Two regions of the mitochondrial DNA (mtDNA) genome were amplified. Primer combination HMND1d (5'-ACTARCTCRGATTCTCCTTCWGCAA-3') and c16sar (5'-CCTCGCCTGTTTAGCAAAAACAT-3') resulted in a product of

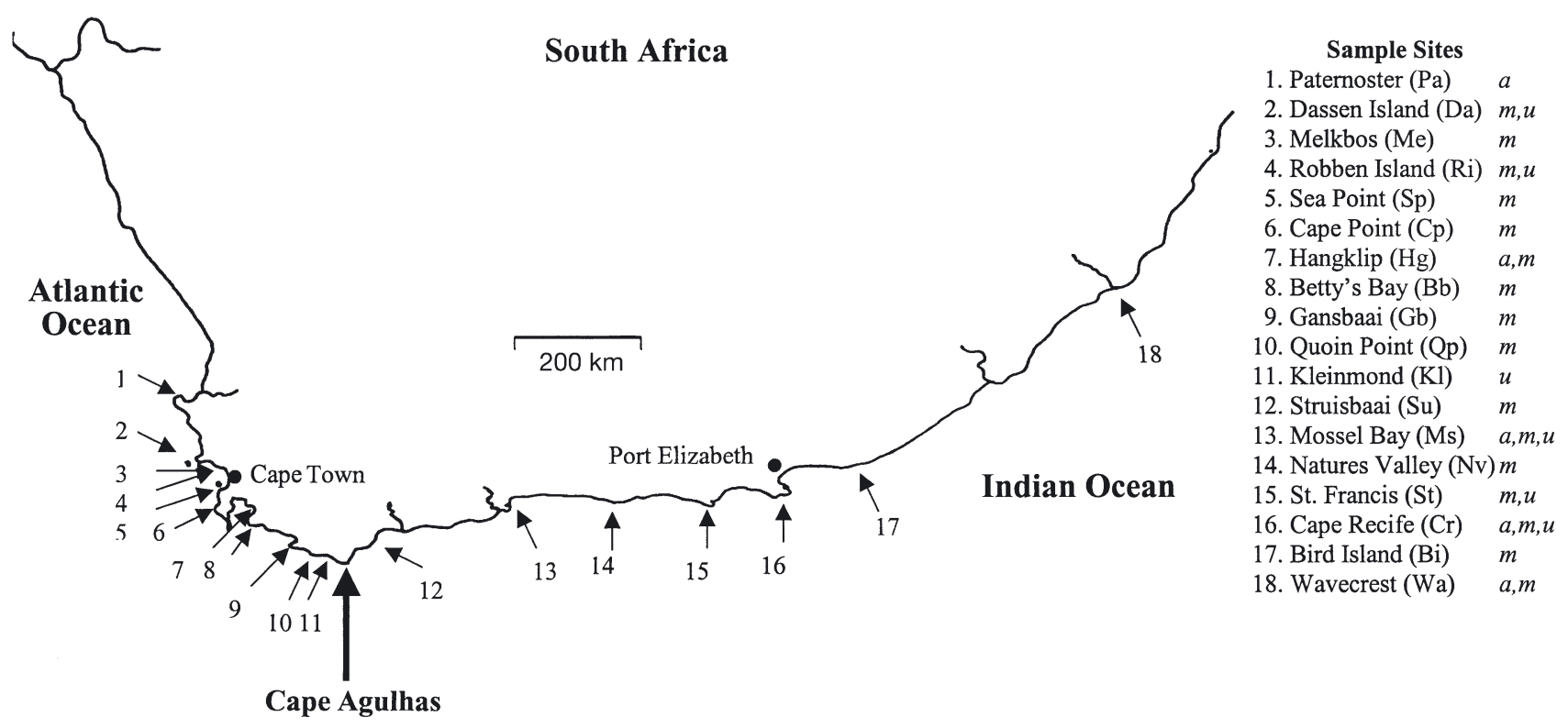

Fig. 1. Sampling locations for Haliotis midae on the South African coast. Samples were analysed for a: allozymes, m: mitochondrial DNA, $u$ : microsatellites 
ca. 1600 base pair (bp) length and contained part of the NADH subunit 1, tRNAs, an unidentified region (ca. $200 \mathrm{bp}$ ) and part of the 16s (subunit) rRNA gene. The primer combination Hmcon (5'-TACTAACACCAAAA CCCCCCC-3') and HMND3 (5'-GAGCCTTCATTT CATTCGTGGA-3') resulted in a product of ca. $1700 \mathrm{bp}$ length containing an unidentified region (ca. $200 \mathrm{bp}$ ), cytochrome oxidase 3 and part of the NADH subunit 3 . PCR reactions consisted of approximately $200 \mathrm{ng}$ total DNA, $200 \mu \mathrm{M}$ of each dNTP (deoxyribo-nucleotide triphosphate: dTTP, dATP, dGTP, dCTP) $50 \mathrm{pM}$ of each primer, $2.5 \mathrm{mM} \mathrm{MgCl}_{2}$ and $2 \mathrm{U}$ Taq DNA polymerase made up to $100 \mu \mathrm{l}$ volume with Milli-Q water. Double the amount of primer HMND1d was used due to its degeneracy. Reactions were performed on a Stratagene Robocycler 96 and comprised a denaturing step of $2 \mathrm{~min}$ at $94^{\circ} \mathrm{C}$ followed by 35 cycles consisting of: denaturation at $94^{\circ} \mathrm{C}(55 \mathrm{~s})$, annealing at $53^{\circ} \mathrm{C}(60 \mathrm{~s})$, and extension at $72^{\circ} \mathrm{C}(3 \mathrm{~min})$. This was followed by a final extension of $10 \mathrm{~min}$ at $72^{\circ} \mathrm{C}$.

Eight restriction endonucleases (Boehringer) were used to examine genetic variability in each amplified region. These comprised five 4-base cutters (Hae III, Hha I, Msp I, Rsa I, Taq I), one 5-base cutter (Hinf I) and two 6-base cutters (BstE II and Sca I). Digests were performed independently for each amplified region in a final volume of $20 \mu \mathrm{l}$. Between 5 and $10 \mu \mathrm{l}$ of PCR product was digested with $5 \mathrm{U}$ restriction endonuclease and $2 \mu \mathrm{l}$ of the appropriate buffer. Digested restriction fragments were electrophoresed on $2 \%(\mathrm{w} / \mathrm{v}$ in Tris-Acetate-EDTA [TAE] buffer) agarose gels incorporating ethidium bromide for UV visualisation. Restriction fragment sizes were determined by comparison to a $100 \mathrm{bp}$ DNA ladder (Boehringer). Where restriction fragment patterns were inconclusive, products were run on $3 \%$ metaphorose gels (FMC Bioproducts), which provide greater resolution of similar sized fragments.

A composite haplotype was produced for each individual describing a multiple restriction endonuclease pattern for the 2 amplified regions combined. Each haplotype was assigned a name HMID- $n$, where $n$ is the number assigned in order of first observation.

Microsatellite DNA : Three primer pairs (CmrHr 2.15, CmrHr 2.23 and CmrHr 2.29 GenBank accession numbers; AF195956, AF302832, AF302834) optimised for amplification of Haliotis midae in a Hybaid 96-well thermocycler were used (Evans et al. 2001). Amplification conditions began with an initial denaturation at $94^{\circ} \mathrm{C}$ for 3 min followed by 30 cycles of denaturation at $94^{\circ} \mathrm{C}(60 \mathrm{~s})$, annealing at $51(\mathrm{CmrHr} 2.23)$ or $53^{\circ} \mathrm{C}(\mathrm{Cm}-$ rHr 2.15 and $\mathrm{CmrHr} 2.29)(45 \mathrm{~s})$, and extension at $72^{\circ} \mathrm{C}$ (60 s). Cycling was followed by a 6 min extension step at $72^{\circ} \mathrm{C}$. Reactions were performed in a volume of $25 \mu \mathrm{l}$ consisting of approximately $200 \mathrm{ng}$ genomic DNA template, $200 \mu \mathrm{M}$ of each dNTP, $7 \mathrm{pM}$ of each primer, either
$1.0 \mathrm{mM}$ (CmrHr 2.23) or $3.0 \mathrm{mM}$ (CmrHr 2.15 and $\mathrm{Cm}$ rHr 2.29) $\mathrm{MgCl}_{2}, 2 \mathrm{U}$ of Taq DNA polymerase (Fisher Biotech) and $\mathrm{ddH}_{2} 0$ to volume. A volume of $5 \mu$ l of each PCR product was electrophoresed on $1 \%$ (w/v in TAE buffer) agarose gels containing ethidium bromide and visualised by UV transillumination to determine whether the reactions were successful. The intensity of these amplifications was used as a guide for dilutions prior to visualisation on an ABI-373 fluorescence system.

From each amplified microsatellite locus, $2 \mu$ was mixed and diluted to a final volume of $80 \mu \mathrm{l} ; 2 \mu \mathrm{l}$ of this dilution was then mixed with formamide, loading dye and Genescan Tamra-500 size standard (ABI, Applied Biosystems Group), denatured at $95^{\circ} \mathrm{C}$ for $2 \mathrm{~min}$, and loaded onto a $4 \%$ denaturing polyacrylamide gel. Samples were run on an ABI-373 DNA autosequencer and genotypes determined with Genotyper® software.

Statistical analysis. Genetic diversity was estimated by the number and frequency of alleles, and the observed $\left(H_{0}\right)$ and Hardy-Weinberg expected $\left(H_{\mathrm{e}}\right)$ heterozygosity for allozyme and microsatellite data, and by the frequency of composite haplotypes, and presence/absence of cut sites for mitochondrial DNA data.

Allozyme genotype frequency departures from Hardy-Weinberg equilibrium (HWE) were tested for all loci and localities using BIOSYS-2 (Swofford \& Selander 1981; modified by J. Black pers. comm.) with Levene's correction for small sample sizes. Mitochondrial DNA haplotype and nucleotide diversity were obtained using REAP ver 4.0 (McElroy et al. 1992).

Allozyme and mtDNA haplotype frequency homogeneity across localities was tested by the randomised Monte Carlo Chi-square procedure of Roff \& Bentzen (1989). For each test 10000 randomisations of data were carried out.

To test the degree of population sub-structure indicated by the mtDNA data, the localities were divided into 2 groups (west and east of Cape Agulhas, Fig. 1) and subjected to an analysis of molecular variance (AMOVA), which allows estimation of the fraction of genetic variance attributable to different hierarchical levels (Excoffier 1993). AMOVA provides a set of $\Phi$ statistics (an analogue of $F$ statistics) for a given geographical hierarchy. Significance values of $\Phi$ statistics and relative variance components were established by comparing observed $F$ values with those obtained from 10000 random permutations of the population haplotype distributions.

Tests for deviations of microsatellite genotypes from HWE within localities were estimated using GENEPOP Ver. 3.2 (Raymond \& Roussett 1995). An index of heterozygote deficiency or excess $\left(D\right.$, where $D=\left[H_{0}-\right.$ $\left.H_{\mathrm{e}}\right] / H_{\mathrm{e}}$ S Selander 1970) was calculated from the heterozygosity estimates. The same program was used to 
assess linkage disequilibrium, homogeneity among localities, and estimates of F-statistics for the microsatellite data. Significance of departure from equilibrium levels was tested by the Markov chain procedure, with significance levels for deviations from HWE based on 100000 steps, for linkage disequilibrium 400 batches of 4000 iterations each, and after 1000 batches of 10000 iterations for homogeneity tests. Wright's fixation index $\left(F_{\mathrm{ST}}\right)$ values for each microsatellite locus were estimated by a weighted ANOVA (Cockerham 1973, Weir \& Cockerham 1984). Where overall estimates of F-statistics were significant, sample pair-wise estimates were obtained to identify the source of the differentiation.

ARLEQUIN Ver. 2.000 (Schneider et al. 2000) was used for ANOVA of microsatellite allele frequencies within and among samples (AMOVA), a method based on Excoffier et al. (1993). Levels of genetic differentia- tion among populations were also calculated using $R_{\mathrm{ST}}$ (as Rho). $R_{\mathrm{ST}}$ is an analogue of $F_{\mathrm{ST}}$, which has been specifically developed for the analysis of microsatellite data. It utilizes a stepwise mutation model (Slatkin 1995) and considers such parameters as variance in allele size and relatively high mutation rates. The RSTcalc package (Goodman 1997) was used to calculate Rho, an unbiased estimator of Slatkin's $R_{\mathrm{ST}}$ that corrects for potential biases that may result from unequal sample sizes and loci with unequal variances. POPGENE Ver. 1.21. (Yeh et al. 1997) was used to produce an unweighted pair group method with arithmetic mean (UPGMA) dendogram, based on Nei's (1972) genetic distance and modified from the NEIGHBOUR procedure of PHYLIP Ver. 3.5.

In all analyses a sequential Bonferroni procedure (Hochberg 1988) was used to account for chances of Type I errors.
Fig. 2. Haliotis midae. UPGMA dendogram of nucleotide divergence (Nei \& Tajima 1981) for the 39 haplotypes sampled. Number of samples and the number of each haplotype at each sampled locality are also given. The 3 main haplotypes, HMID-1, HMID-2, HMID-9, are in bold. Locality name abbreviations are given in Fig. 1
0.001

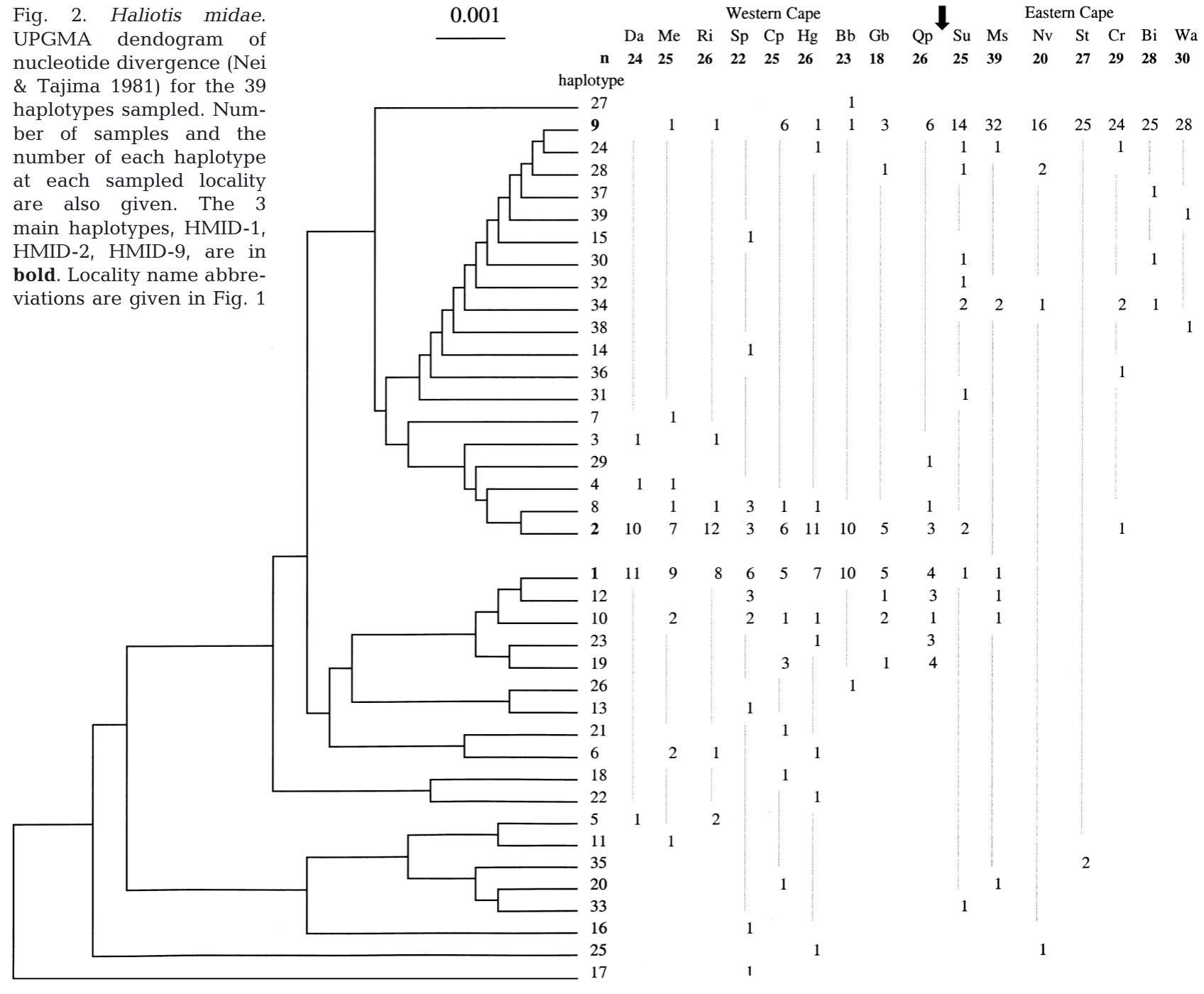

\begin{tabular}{lllllllllllllllll}
\multicolumn{1}{c}{ Western Cape } & \multicolumn{1}{c}{ Eastern Cape } \\
$\mathrm{Da}$ & $\mathrm{Me}$ & $\mathrm{Ri}$ & $\mathrm{Sp}$ & $\mathrm{Cp}$ & $\mathrm{Hg}$ & $\mathrm{Bb}$ & $\mathrm{Gb}$ & $\mathrm{Qp}$ & $\mathrm{Su}$ & $\mathrm{Ms}$ & $\mathrm{Nv}$ & $\mathrm{St}$ & $\mathrm{Cr}$ & $\mathrm{Bi}$ & $\mathrm{Wa}$
\end{tabular} $\begin{array}{lllllllllllllllll}n & 24 & 25 & 26 & 22 & 25 & 26 & 23 & 18 & 26 & 25 & 39 & 20 & 27 & 29 & 28 & 30\end{array}$ haplotype 


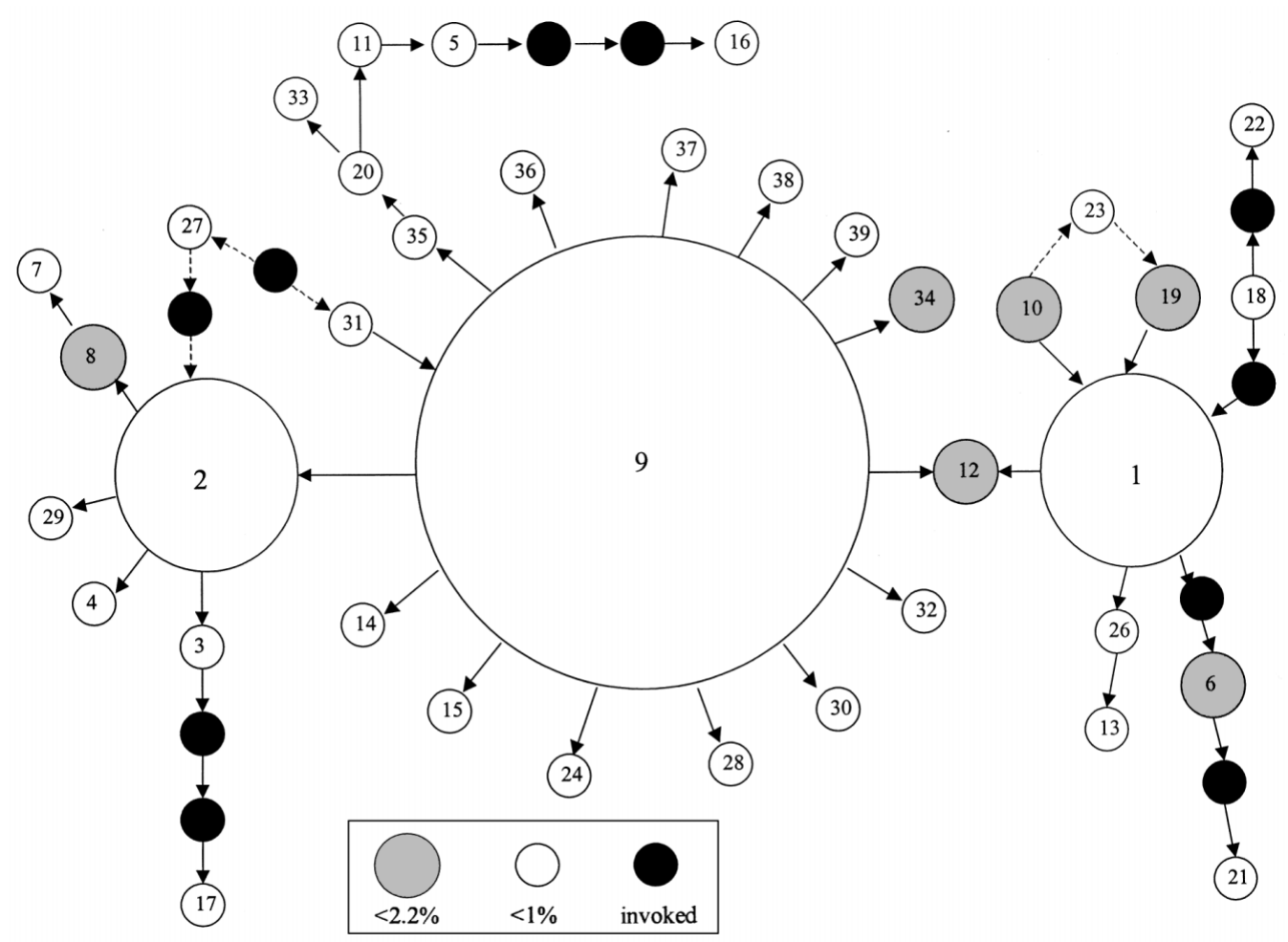

Fig. 3. Haliotis midae. Possible haplotype relationship network. Diameter of circles is proportional to frequency. Each arrow represents one restriction-site difference. Direction of the arrow indicates the gain of a site. Broken lines represent examples of equally parsimonious options

\section{RESULTS}

\section{Allozyme electrophoresis}

Of the 7 allozyme loci resolved, 5 were polymorphic at all 5 localities, with a mean of 3.8 to 4.4 alleles per locus (Appendix 1; at www.int-res.com/journals/suppl/ Evans_appendices.pdf). Mean observed heterozygosity across all 7 loci ranged from 0.264 to 0.306 (mean $0.289 \pm 0.026)$ and average expected heterozygosity (Nei 1978) ranged from 0.301 to 0.326 (mean $0.311 \pm$ 0.012). The only significant deviation from HardyWeinberg predicted genotype frequencies was for the mpi-1 locus in the Cape Recife sample ( $\mathrm{p}<0.01)$.

Highly significant heterogeneity $\left(\mathrm{p}<0.001, \chi^{2}{ }_{\text {obs }}=\right.$ $39.9, \chi^{2}$ null $\left.=16.1\right)$ within the data set was suggested at 1 locus (mpi-1) following $\chi^{2}$ tests of allele frequency distributions. Heterogeneity $\left(p<0.05, \chi^{2}{ }_{\text {obs }}=27.1, \chi^{2}\right.$ null $=15.9$ ) at the dia-1 locus was not significant after Bonferroni correction for multiple tests. Pair-wise comparisons between localities at the mpi-1 locus were significantly $(p<0.001)$ different between the most western locality, Paternoster, and the 2 eastern localities, Cape Recife $\left(\chi_{\text {obs }}^{2}=12.8, \chi_{\text {null }}^{2}=4.0\right)$ and Wavecrest $\left(\chi_{\text {obs }}^{2}=\right.$ 19.9, $\left.\chi_{\text {null }}^{2}=4.0\right)$. These 2 eastern localities differed from the Hangklip locality $\left(\chi_{\text {obs }}^{2}=9.6, \chi^{2}\right.$ null $=4.1 ; \chi^{2}$ obs $=9.3, \chi^{2}$ null $=4.0$, respectively) but the significance $(\mathrm{p}<$ 0.05) was not valid after Bonferroni corrections were applied. Mossel Bay was also significantly different to
Wavecrest at mpi-1 $\left(\mathrm{p}<0.01, \chi_{\text {obs }}^{2}=13.3, \chi_{\text {null }}^{2}=4.0\right)$. The marginally significant result at dia-1 was between Mossel Bay and the 2 eastern localities of Cape Recife and Wavecrest; however, after correction, the differences were not significant.

Geographic structuring was further examined using $F_{\text {ST }}$ statistics. While overall less than $1 \%$ of the genetic variability detected could be attributed to population substructure, at the mpi-1 locus, the $F_{\mathrm{ST}}$ value across all localities was 0.031 .

\section{Mitochondrial DNA}

A total of 39 composite haplotypes were observed in the 413 individual Haliotis midae examined from the 16 localities (Fig. 2). The number of variants of composite restriction fragment patterns ranged from 3 (Hha I and BstE II) to 6 (Taq I). Over the 2 regions of mtDNA amplified, 51 recognition sites sampling $225 \mathrm{bp}$ were analysed. Of these, 22 were fixed and 29 polymorphic, and 13 phylogenetically informative (variation in more than 1 haplotype). The fragment HMcon-HMND3 (ca. 1700 bp) was only ca. 100 bp larger than the HMND1d-c16sar fragment, but $62 \%$ of the data were obtained from this larger fragment.

Fig. 3 displays the relative frequency of the sampled haplotypes. Most of the haplotypes are related to one another by the gain or loss of one recognition site. In 
Table 1. Haliotis midae. MtDNA variability data

\begin{tabular}{|lcc|}
\hline Sample & $\begin{array}{c}\text { Haplotype } \\
\text { diversity }\end{array}$ & $\begin{array}{c}\text { Nucleotide } \\
\text { diversity }\left(\times 10^{2}\right)\end{array}$ \\
\hline West of Cape Agulhas & & \\
Dassen Island (Da) & 0.6377 & 0.0064 \\
Melkbostrand (Me) & 0.8033 & 0.0070 \\
Robben Island (Ri) & 0.7077 & 0.0072 \\
Sea Point (Sp) & 0.8918 & 0.0088 \\
Cape Point (Cp) & 0.8567 & 0.0061 \\
Cape Hangklip (Hg) & 0.7662 & 0.0074 \\
Betty's Bay (Bb) & 0.6443 & 0.0057 \\
Gansbaai (Gb) & 0.8431 & 0.0049 \\
Quoin Point (Qp) & 0.8892 & 0.0050 \\
Mean & 0.7822 & 0.0065 \\
East of Cape Agulhas & & \\
Struisbaai (Su) & 0.6900 & 0.0034 \\
Mossel Bay (Mb) & 0.3293 & 0.0014 \\
Natures's Valley (Nv) & 0.3632 & 0.0022 \\
St Francis Bay (St) & 0.1425 & 0.0004 \\
Cape Recife (Cr) & 0.3177 & 0.0012 \\
Bird Island (Bi) & 0.2063 & 0.0007 \\
Wave Crest (Wa) & 0.1310 & 0.0004 \\
Mean & 0.3114 & 0.0014 \\
Overall mean & $\mathbf{0 . 5 7 6 2}$ & $\mathbf{0 . 0 0 4 3}$ \\
& & \\
\hline
\end{tabular}

some cases, haplotypes could not be matched to any other in the sample on the basis of a single recognition site change. Thus, in 2 cases, 2 adjacent intermediate unsampled haplotypes had to be invoked, and in 5 cases, a single intermediate unsampled haplotype was required in order to construct the diagram. Three haplotypes, HMID-1 at $16.2 \%$, HMID-2 at $16.9 \%$ and HMID-9 at $44.3 \%$, accounted for $77.4 \%$ of the individuals (Fig. 2). Only one other haplotype appeared at a frequency $>2 \% ; 21(53.8 \%)$ of the composite haplotypes occurred at 1 locality only (private haplotypes), and 11 of the 16 localities produced private haplotypes, 5 with 1, 5 with 2 and 1 (Sea Point) with 5 different private haplotypes. The distribution of haplotypes by locality is presented in Fig. 2.

The geographic distribution of the composite haplotypes is characterised by significant variation between localities west and east of Cape Agulhas (Fig. 2). Firstly, 29 haplotypes occurred in the 215 individuals from west of the Cape and only 19 from the 198 individuals from east of the Cape; 20 haplotypes occurred only in the west localities, while 9 were exclusive to the eastern localities. The dominant haplotype (HMID-9) was predominant in eastern localities $(83 \%)$, while HMID-1 and -2 were predominant in western localities (61\%) (Fig. 2).

Both haplotype and nucleotide diversities calculated for each locality also displayed a conspicuous difference between the samples from the east and west of Cape Agulhas (Table 1). Within-sample haplotype diversity measures for the eastern localities are on average less than half that of the western localities, and nucleotide diversity is less than a third.

Highly significant heterogeneity of haplotype frequency distributions was detected among all localities, and between combined localities from the west and east of Cape Agulhas (Table 2). No heterogeneity was detected among localities within the eastern region, yet significant heterogeneity was detected within the western region (Table 2).

Pair-wise tests confirm the east-west split, but also indicate that the break between west and east is not sharply defined at Cape Agulhas. Among the eastern localities the only significant result was for the most easterly sample (Wavecrest) with Struisbaai, the most westerly and closest to Cape Agulhas. All pair-wise tests between western localities and Struisbaai indicated significant heterogeneity except for Gansbaai and Quoin Point, the 2 most easterly and closest to Cape Agulhas. Also, the more western localities revealed significant heterogeneity with Quoin Point. Within the western region, significant heterogeneity ( $p<0.001$, Table 2$)$ was observed when pooling the more western samples (Dassen Island to Sea Point) and comparing to the SW coast samples (Cape Point to Quoin Point).

AMOVA for the subdivision of samples into an eastern and western grouping (Dassen Isaland to Quoin Point versus Struisbaai to Wavecrest) reveals that almost $40 \%$ (between groupings $\Phi_{\mathrm{CT}}=0.387$; within groupings $\Phi_{\mathrm{CT}}=0.031$ ) of the total genetic variance is attributable to differentiation between these 2 groupings.

\section{Microsatellite DNA}

Within the 6 localities analysed, 19 alleles were detected at locus $\mathrm{CmrHr} 2.15,2$ at $\mathrm{CmrHr} 2.23$ and 17 at $\mathrm{CmrHr} 2.29$ (Appendix 2; at www.int-res.com/jour-

Table 2. Haliotis midae. Heterogeneity tests of mtDNA haplotype frequencies, from 1000 permutations of various groupings. ${ }^{*}$ Not significant after sequential Bonferroni correction; ns: not significant. For locality name abbreviations, see Fig. 1

\begin{tabular}{|lrrc|}
\hline Grouping & $\chi^{2}{ }_{\text {obs }}$ & $\chi^{2}{ }_{\text {null }}$ & $\mathrm{p}$ \\
\hline All localities & 947.98 & 571.68 & $<0.0001$ \\
East vs West & 318.08 & 38.06 & $<0.0001$ \\
All West (Da to Qp) & 279.27 & 24.78 & $<0.001$ \\
All East (Su-Wa) & 84.47 & 75.44 & $\mathrm{~ns}$ \\
Wcst vs SWcst & 44.30 & 28.05 & $<0.001$ \\
Wcst (Da-Sp) & 60.09 & 48.43 & $<0.05^{*}$ \\
SWcst (Cp-Qp) & 86.53 & 72.61 & $<0.05^{*}$ \\
& & & \\
\hline
\end{tabular}


nals/suppl/Evans_appendices.pdf). Mean observed heterozygosity per locality across all 3 loci range from 0.333 to 0.471 , and average expected heterozygosity from 0.490 to 0.567 . Observed locus heterozygosity ranged from 0.167 ( $\mathrm{CmrHr} 2.23$ at Dassen Island) to 0.627 (CmrHr 2.29 at Cape Recife) (Appendix 3; at www.int-res.com/journals/suppl/Evans_appendices.pdf). Three of the 18 tests for genotype conformance to Hardy-Weinberg expectations differed significantly after sequential Bonferroni correction (Appendix 3); all 3 were for locus $\mathrm{CmrHr}$ 2.15. Negative values of Selander $D$-index (Selander 1970) were obtained for 16 of the 18 tests, indicating an overall deficit of heterozygotes.

Highly significant differentiation in allele frequencies across the 6 localities was found by exact tests at 2 loci; $\mathrm{p}<0.0001$ at locus $\mathrm{CmrHr} 2.15, \mathrm{p}=0.5510$ at locus $\mathrm{Cm}$ rHr 2.23, and $\mathrm{p}=0.0014$ at locus $\mathrm{CmrHr} 2.29$. Sample pair-wise $R_{\mathrm{ST}}$ and $F_{\mathrm{ST}}$ tests across all loci returned highly significant differences between locality pairs that, like the mtDNA results, suggested discontinuity to the east and west of Cape Agulhas (Table 3). This result was supported by AMOVA results when the 3 western localities were compared to the 3 eastern localities, with an overall $F_{\mathrm{ST}}$ of 0.033 (Table 4). No significant difference was detected within either group.

Shifts in number of alleles and frequency of the more common allele between the east and west of Cape Agulhas were observed at 2 loci (Appendix 2). In a total of 108 individuals analysed from west of the Cape, 18 alleles were observed at $\mathrm{CmrHr} 2.15$, and 17 at $\mathrm{CmrHr}$ 2.29. East of Cape Agulhas, in 127 individuals analysed, only 11 and 10 alleles, respectively, were observed. This trend was maintained when localities were examined independently. At $\mathrm{CmrHr} 2.15$, the $277 \mathrm{bp}$ allele was present at a frequency of 0.374 in the western samples, but at the much higher frequency of 0.615 in the eastern samples. Likewise, the $462 \mathrm{bp}$ allele at $\mathrm{CmrHr} 2.29$ changed from a frequency of 0.513 in the west to 0.340 in the east. These changes

Table 3. Haliotis midae. Microsatellite DNA-derived sample pair-wise $R_{\mathrm{ST}}$ values, presented as Rho below diagonal, and population pair-wise $F_{\mathrm{ST}}$ (Wright's fixation index) values above diagonal. ${ }^{* *}$ Significant pair-wise differentiation after sequential Bonferroni correction. For locality name abbreviations see Fig. 1

\begin{tabular}{|lccclll|}
\hline & Da & \multicolumn{1}{c}{$\mathrm{Ri}$} & \multicolumn{1}{c}{$\mathrm{Kl}$} & \multicolumn{1}{c}{$\mathrm{Ms}$} & \multicolumn{1}{c}{$\mathrm{St}$} & \multicolumn{1}{c}{$\mathrm{Cr}$} \\
\hline $\mathrm{Da}$ & - & 0.001 & 0.002 & 0.030 & 0.024 & 0.001 \\
$\mathrm{Ri}$ & 0.019 & - & -0.002 & $0.065^{* *}$ & $0.067^{* *}$ & 0.022 \\
$\mathrm{Kl}$ & 0.013 & -0.011 & - & $0.067^{* *}$ & $0.059^{* *}$ & $0.028^{* *}$ \\
$\mathrm{Ms}$ & 0.019 & $0.059^{* *}$ & $0.055^{* *}$ & - & 0.026 & 0.004 \\
$\mathrm{St}$ & 0.058 & $0.133^{* *}$ & $0.111^{* *}$ & 0.027 & - & 0.012 \\
$\mathrm{Cr}$ & 0.000 & $0.035^{* *}$ & 0.024 & 0.000 & 0.028 & - \\
& & & & & & \\
\hline
\end{tabular}

are not countered by opposing shifts in flanking allele frequencies, and so are unlikely to be due to the misscoring of alleles.

Nei's (1972) genetic distances between localities based on the variation at 3 microsatellite loci are represented in an UPGMA dendogram (Fig. 4). The pairwise values range from a minimum of 0.013 between Robben Island and Kleinmond to a maximum of 0.096 between Robben Island and St. Francis.

\section{DISCUSSION}

We have presented an analysis of allozyme, mitochondrial and microsatellite genetic variation in Haliotis midae from southern Africa, and provided strong evidence of genetic structuring in this abalone species at 2 of these genetic markers. The genetic structuring, with a boundary in the Cape Agulhas region, aligns with the oceanography of the South African coast (Beckley et al. 2002).

Both allozyme and mitochondrial DNA data are characterised by a high degree of variability. However, at the mitochondrial DNA marker, samples taken from the west of Cape Agulhas had a higher diversity in comparison to those from the east. Measures of diversity in the east are not intrinsically low, however, and similar to measures reported for other molluscs (e.g. the scallop Placopecten yessoensis; Boulding et al. 1993).

Average heterozygosity $\left(H_{\mathrm{e}}\right)$ across 3 microsatellite loci was higher in samples from the west of Cape Agulhas (0.547) than those from the east (0.510). The values are low compared to average $H_{\mathrm{e}}$ reported at microsatellite loci in other abalone species (range: 0.908 to 0.756: Huang et al. 2000, Conod et al. 2002). A possible explanation for the lower heterozygosity is the use of microsatellite markers originally designed for Haliotis rubra (cf. the review of microsatellite characteristics in vertebrates by Neff \& Gross 2001). The probing and hybridisation process in the screening of microsatel-

Table 4. Haliotis midae. Microsatellite DNA-derived analysis of molecular variance (AMOVA), comparing a group of 3 samples to the west of Cape Agulhas to a group of 3 samples east of that point. Estimates of $\Phi_{\mathrm{CT}}$ obtained using Arlequin Ver. $2.000{ }^{* *}$ Significant differentiation after sequential Bonferroni correction for multiple tests. $\mathrm{N}$ : sample size; $\mathrm{N}_{\text {allele: }}$ number of alleles

\begin{tabular}{|lccl|}
\hline Locus & $\mathrm{N}$ & $\mathrm{N}_{\text {allele }}$ & $\Phi_{\mathrm{CT}}$ \\
\hline CmrHr 2.15 & 199 & 19 & $0.059^{* *}$ \\
CmrHr 2.23 & 205 & 2 & 0.006 \\
CmrHr 2.29 & 205 & 17 & $0.013^{* *}$ \\
All & 203 & 12.7 & $0.033^{* *}$ \\
\hline
\end{tabular}


Fig. 4. Haliotis midae. UPGMA dendogram of Nei's (1972) genetic distances based on microsatellite DNA variation among samples from across the species range
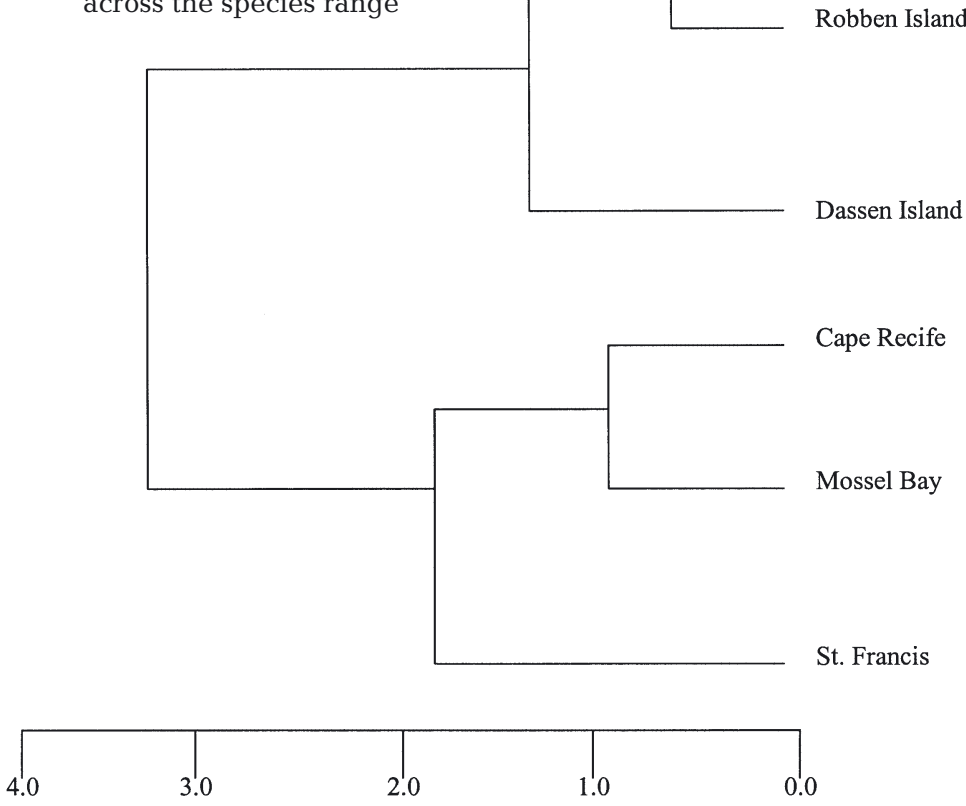

Genetic Distance

lites may either directly select, or researchers selectively report, longer microsatellite loci. Perhaps due to the association of allele length and microsatellite variation, this often leads to a reduction in heterozygosity in non-target species (e.g. Ellegren et al. 1997). This theory is supported by lower heterozygosity detected in $H$. laevigata samples, again examined using markers designed for H. rubra (N. Conod, B. S. Evans, N. G. Elliott pers. comm.).

All departures from Hardy-Weinberg equilibrium at 1 microsatellite locus were the result of heterozygote deficiencies, which are not uncommon in marine molluscs (Zouros \& Pogson 1994, Huang et al. 2000, McGoldrick et al. 2000, Conod et al. 2002). The deviations were not consistent across samples and are therefore unlikely to be explained by inbreeding or the Wahlund effect (Richardson 1982). A common suggestion for heterozygote deficiency is the presence of null or non-amplifying alleles, most probably caused by mutations within the PCR primer regions. The confirmation of null alleles at other Haliotis rubra microsatellite loci (B. S. Evans \& N. G. Elliott unpubl. data) suggests that the homozygote excess detected in $H$. midae at locus $\mathrm{CmrHr} 2.15$ could be due to the presence of null alleles.

Both the mtDNA and the microsatellite data demonstrate significant genetic structuring within the Haliotis midae population along the coast of South Africa. The
Kleinmond mitochondrial DNA data presents a $\sum_{\infty}$ clearer picture of the differentiation. In the samples to the west of Cape Agulhas, haplotypes HMID-1 and -2 dominate at almost equal frequencies (30 and $31 \%$ ), while the samples to the east of the Cape are dominated by haplotype HMID-9 (83\%), which is relatively rare in the west $(9 \%)$. Most of the remaining haplotypes in the eastern region are closely related to haplotype HMID-9 in terms of nucleotide sequence divergence (Figs. $2 \& 3$ ), and are likely to have arisen from mutations from that haplotype. This would be consistent with a population bottleneck or founder effect in the eastern region, with relatively reduced variation followed by diversification in a reproductively isolated stock (Ovenden \& White 1990).

The microsatellite results are consistent with the west-east differentiation of the population around Cape Agulhas, but show no further structure within either group. The level of genetic isolation of the west and east samples shown by the microsatellites $\left(\Phi_{\mathrm{ST}}=0.033\right)$, while relatively high compared to other studies (e.g. Brown 1991, allozymes $F_{\mathrm{ST}}=0.022$; Hancock 2000, allozymes $F_{\mathrm{ST}}=0.009$; Conod et al. 2002, microsatellites $F_{\mathrm{ST}}=0.003$ ), is an order of magnitude lower than that observed for the mtDNA data $\left(\Phi_{\mathrm{ST}}=0.387\right)$. Hamm \& Burton (2000) reported a similar value at allozyme loci in Haliotis cracherodii $\left(\mathrm{F}_{\mathrm{ST}}=0.039\right)$, but that differentiation was, however, not supported by mtDNA data collected from the same samples. In our study, the microsatellite and mtDNA analyses both provide strong support to the dramatic discontinuity in the $H$. midae population to the east and west of Cape Agulhas, albeit a stronger result from the mtDNA data.

The eastern distribution of Haliotis midae (east of Cape Agulhas) is presumably the result of a recent (in geological terms) range expansion in that direction, thus the relatively lower diversity in the eastern samples. High levels of genetic diversity are the result of the accumulation of neutral mutations aided by large population sizes and long evolutionary time periods (Lacey 1987, Sole-Cava \& Thorpe 1991, Woodworth et al. 1994). Both these criteria are met in relation to $H$. midae. Presumptive ancestors of this species dating back to the late tertiary and beyond have been discovered in the western cape of South Africa (Kensley \& Pether 1986, J. Pether pers. comm.). Also, population sizes of $H$. midae are more substantial in the western region and are likely to have been even larger historically, prior to exploitation. 
If the migration to the east of the Cape were a single introduction event, with all markers being selectively neutral, we would anticipate a mitochondrial DNA analysis, as it has, to show the strongest signs of a founder effect. This is due to its maternal inheritance and haploid nature combining to reduce its effective population size to a quarter that of nuclear markers (Avise 1994).

If the easterly population were then reproductively isolated from that to the west of Cape Agulhas for a sufficient time period, the 2 populations would diverge through genetic drift and mutation. We would expect microsatellite markers, with high mutation rates (Freeland et al. 2000), to also begin to show signs of differentiation between the 2 populations. This rapid mutation rate could also be expected to ensure that any loss of heterozygosity in the population to the east would be quickly hidden by the relatively fast allele frequency changes that result. In addition, a mutation may simply produce an existing allelic state, rather than a new allele each time. Therefore, a founder population may take longer to recover from a loss of alleles than the associated loss of heterozygosity. A reduction in the number of microsatellite alleles in the eastern samples and allele frequency changes between west and east are suggestive of a founder event (Allendorf \& Ryman 1988) into waters east of Cape Agulhas.

Karl \& Avise (1992) cite numerous examples where data from allozyme loci indicate little or no population subdivision, yet mtDNA studies later reveal discontinuities (e.g. Ovenden \& White 1990). Karl \& Avise (1992) suggest that in oysters, the lack of differentiation at allozyme loci can be attributed to balancing selection on protein coding loci. They reach this conclusion based on discontinuities at nuclear genes that are similar to those described by mtDNA data, despite a complete lack of population subdivision detected at allozyme loci in the same samples. Their conclusion, and ours, emphasises the need for caution when inferring population genetic structure and gene flow from any single class of genetic marker.

Burton (1996) concluded that the choice of a molecular technique to a given problem should be based on its efficiency. We have shown that the PCR-RFLP of mtDNA is an efficient method to infer population structure in Haliotis midae. The highly polymorphic microsatellite DNA markers support the differentiation of the east and west populations of $H$. midae, but do not reveal any finer-scale subdivision.

We conclude that populations of Haliotis midae on either side of Cape Agulhas represent 2 independent reproductive stocks. Evidence from allozyme, mitochondrial DNA and microsatellite data supports an isolated introduction event to the east of Cape Agulhas, and subsequent range expansion in an easterly direc- tion. The disparity between allozyme data and that from mtDNA and microsatellites is seen as further evidence for the presence of balancing selection (as described by Karl \& Avise 1992) at allozyme loci.

Acknowledgements. We thank G. Harms for the use of the ABI-373 at Groote Schur Hospital, Cape Town. We gratefully acknowledge A. Smolenski, S. Jarman and R. Ward for helpful comments on drafts of this manuscript. This work was funded by a grant from I\&J Fisheries, South Africa. Travel funding was provided for B.S.E. to visit Cape Town by Aquaculture CRC and the University of Tasmania.

\section{LITERATURE CITED}

Allendorf FW, Ryman N (1988) Genetic management of hatchery stocks. In: Ryman N, Utter FW (eds) Population genetics and fishery management. University of Washington Press, Seattle, p 141-159

Avise JC (1994) Molecular markers, natural history and evolution. Chapman \& Hall, New York

Beckley LE, Hulley PA, Skelton PH (2002) Synoptic overview of marine ichthyology in South Africa. Mar Freshw Res 53:99-105

Benson PG, Smith PJ (1989) A manual of techniques for electrophoretic analysis of fish and shellfish tissues. NZ Fish Tech Rep 13, p 13

Boulding EG, Boom JDG, Beckenbach AT (1993) Geneticvariation in one bottlenecked and two wild populations of the Japanese scallop (Patinopecten yessoensis) - empirical parameter estimates from coding regions of mitochondrial-DNA. Can J Fish Aquat Sci 50: 1147-1157

Brown LD (1991) Genetic variation and population structure in the blacklip abalone, Haliotis rubra. Aust J Mar Freshw Res 42:77-90

Burton RS (1996) Molecular tools in marine ecology. J Exp Mar Biol Ecol 200:85-101

Cockerham CC (1973) Analyses of gene frequencies. Genetics 74:679-700

Conod N, Bartlett J, Evans BS, Elliott NG (2002) Comparison of mitochondrial and nuclear DNA analyses of population structure in the blacklip abalone Haliotis rubra Leach. Mar Freshw Res 53:711-718

Ellegren H, Moore S, Robinson N, Byrne K, Ward W, Sheldon BC (1997) Microsatellite evolution - a reciprocal study of repeat lengths at homologous loci in cattle and sheep. Mol Biol Evol 14:854-860

Evans BS, Conod N, Elliott NG (2001) Evaluation of microsatellite primer conservation in abalone. J Shellfish Res 20:1065-1070

Excoffier L (1993) WINAMOVA Ver. 1.5: analysis of molecular variance. Genetics and Biometry Laboratory, University of Geneva, Geneva, also avilable from the Zoology Institute, University of Bern at http://cmpg.unibe.ch/excoffier/ default.htm

Freeland JR, Noble LR, Okamura B (2000) Genetic diversity of North American populations of Cristatella mucedo, inferred from microsatellite and mitochondrial DNA. Mol Ecol 9:1375-1389

Geiger DL (2000) Distribution and biogeography of the recent Haliotidae (Gastropoda: Vetigastopoda) world-wide. Boll Malacol 35:5-12

Goodman SJ (1997) RST CALC: a collection of computer programs for calculating unbiased estimate of genetic differ- 
entiation and gene flow from microsatellite data and determining their significance. Mol Ecol 6:881-885

Grewe PM, Kreuger CC, Aquadro CF, Bermingham E, Kincaid HL, May B (1993) Mitochondrial DNA variation among lake trout (Salvelinus namaycush) strains stocked into Lake Ontario. Can J Fish Aquat Sci 50:2397-2403

Hamm DE, Burton RS (2000) Population genetics of the black abalone, Haliotis cracherodii, along the central Californian coast. J Exp Mar Biol Ecol 254:235-247

Hancock B (2000) Genetic subdivision of Roe's abalone, Haliotis roei Grey (Mollusca: Gastropoda), in southwestern Australia. Mar Freshw Res 51:679-687

Hilbish TJ (1996) Population genetics of marine species: the interaction of natural selection and historically differentiated populations. J Exp Mar Biol Ecol 200:67-83

Hochberg Y (1988) A sharper Bonferroni procedure for multiple tests of significance. Biometrika 75:800-802

Huang BX, Pakall R, Hanna PJ (2000) Analysis of genetic structure of blacklip abalone (Haliotis rubra) populations using RAPD, minisatellite and microsatellite markers. Mar Biol 136:207-216

Karl SA, Avise JC (1992) Balancing selection at allozyme loci in oysters: implications from nuclear RFLPs. Science 256: 100-102

Kensley BF (1972) Pliocene marine invertebrates from Langebaanweg, Cape Province. Ann SA Mus 60:73-190

Kensley BF, Pether J (1986) Late tertiary and early quaternary fossil mollusca of the Hondeklip area, Cape Province, South Africa. Ann SA Mus 97:141-225

Lacey RC (1987) Loss of genetic diversity from managed populations: interacting effects of drift, mutation, immigration, selection and population subdivision. Conserv Biol 1:143-158

McElroy D, Moran P, Bermingham E, Kornfield I (1992) REAP - an integrated environment for the manipulation and phylogenetic analysis of restriction data. J Heredity 83:157-158

McGoldrick DJ, Hedgecock D, English LJ, Baoprasertkul P, Ward RD (2000) The transmission of microsatellite alleles in Australian and North American stocks of the Pacific oyster (Crassostrea gigas): selection and null alleles. J Shellfish Res 19:779-788

Neff BD, Gross MR (2001) Microsatellite evolution in vertebrates: inference from AC dinucleotide repeats. Evolution 55:1717-1733

Nei M (1972) Genetic distance between populations. Am Nat 106:283-292

Nei M (1978) Molecular evolutionary genetics. Columbia University Press, New York

Ovenden JR, White RWG (1990) Mitochondrial and allozyme genetics of incipient speciation in a landlocked population of Galaxias truttaceus (Pisces: Galaxiidae). Genetics 124: 701-706

Editorial responsibility: Otto Kinne (Editor),

Oldendorf/Luhe, Germany
Raymond M, Rousset F (1995) GENEPOP (Ver. 1.2): population genetic software for exact tests and ecumenicism. J Heredity 86:248-249

Richardson BJ (1982) Geographical distribution of electrophoretically detected protein variation in Australian commercial fishes. I. Jack mackerel Trachurus declivus Jenyns. Aust J Mar Freshw Res 33:917-926

Roff DA, Bentzen P (1989) The statistical analysis of mitochondrial DNA polymorphisms: $\chi^{2}$ and the problem of small samples. Mol Biol Evol 6:539-545

Schaal BA, Anderson WW (1974) An outline of techniques for starch gel electrophoresis of enzymes from the American oyster Crassostrea virginica Gmelin. Technical report series No. 74-3, Georgia Marine Science Centre, Savannah

Schneider S, Kueffer JM, Roessli D, Excoffier L (2000) ARLEQUIN (Ver. 2.000): software for population genetic data analysis. Genetics and Biometry Laboratory, University of Geneva, Geneva

Selander RK (1970) Behavior and genetic variation in natural populations. Am Zool 10:53-66

Shaklee JB, Bentzen P (1998) Genetic identification of stocks of marine fish and shellfish. Bull Mar Sci 62:589-621

Slatkin M (1995) A measure of population subdivision based on microsatellite allele frequencies. Genetics 139:457-462

Sokal RR, Rohlf FJ (1981) Biometry, 2nd edn. WH Freeman, New York

Sole-Cava AM, Thorpe JP (1991) High levels of genetic variation in natural populations of marine lower invertebrates. Biol J Linn Soc 44:65-80

Swofford DL, Selander RB (1981) BIOSYS-1: a FORTRAN program for the comprehensive analysis of electrophoretic data in population genetics and systematics. J Heredity 72:281-283

Turpie JK, Beckley LE, Katua SM (2000) Biogeography and the selection of priority areas for conservation of South African coastal fishes. Biol Conserv 92:59-72

Ward RD, Grewe PM (1994) Appraisal of molecular genetic techniques in fisheries. Rev Fish Biol Fish 4:300-325

Weir BS, Cockerham CC (1984) Estimating F-statistics for the analysis of population structure. Evolution 38:1358-1370

Woodworth LM, Montgomery ME, Nurthen RK, Briscoe DA, Frankham R (1994) Modelling problems in conservation genetics using Drosophila: consequences of fluctuating population sizes. Mol Ecol 3:393-399

Yeh FC, Yang R, Boyle Tyez, Mao JX (1997) POPGENE, the user-friendly shareware for population genetic analysis, Ver. 1.21. Molecular Biology and Biotechnology Centre, University of Alberta, Canada

Zouros E, Pogson GH (1994) The present status of the relationship between heterozygosity and heterosis. In: Beaumont AR (ed) Genetics and evolution of aquatic organisms. Chapman \& Hall, London

Submitted: June 19, 2003; Accepted: December 9, 2003 Proofs received from author(s): March 31, 2004 